\title{
Maastricht University Graduate Surveys 2020
}

Citation for published version (APA):

Aarts, B., \& Künn, A. (2020). Maastricht University Graduate Surveys 2020. ROA. ROA Fact Sheets No. 003 https://doi.org/10.26481/umarof.2020003

Document status and date:

Published: 16/06/2020

DOI:

10.26481/umarof.2020003

Document Version:

Publisher's PDF, also known as Version of record

\section{Please check the document version of this publication:}

- A submitted manuscript is the version of the article upon submission and before peer-review. There can be important differences between the submitted version and the official published version of record.

People interested in the research are advised to contact the author for the final version of the publication, or visit the DOI to the publisher's website.

- The final author version and the galley proof are versions of the publication after peer review.

- The final published version features the final layout of the paper including the volume, issue and page numbers.

Link to publication

\footnotetext{
General rights rights.

- You may freely distribute the URL identifying the publication in the public portal. please follow below link for the End User Agreement:

www.umlib.nl/taverne-license

Take down policy

If you believe that this document breaches copyright please contact us at:

repository@maastrichtuniversity.nl

providing details and we will investigate your claim.
}

Copyright and moral rights for the publications made accessible in the public portal are retained by the authors and/or other copyright owners and it is a condition of accessing publications that users recognise and abide by the legal requirements associated with these

- Users may download and print one copy of any publication from the public portal for the purpose of private study or research.

- You may not further distribute the material or use it for any profit-making activity or commercial gain

If the publication is distributed under the terms of Article $25 \mathrm{fa}$ of the Dutch Copyright Act, indicated by the "Taverne" license above, 
Maastricht University $\&$ ROA

\section{Maastricht University Graduate Surveys 2020}

Bas Aarts

Annemarie Künn

\section{ROA Factsheet}

ROA-F-2020/3

Researchcentrum voor Onderwijs en Arbeidsmarkt | ROA Research Centre For Education and the Labour Market / ROA 


\section{Maastricht University Graduate Surveys 2020}

How well does Maastricht University (UM) prepare its students for the labour market? What do the career paths of UM alumni look like in the short and medium term, and how do they look back on their master's studies in Maastricht? To what extent do graduates possess the competencies valued most by employers while hiring? And to what extent do graduates perceive that the UM contributed in the acquisition of these competencies? This factsheet reports on the employability of graduates of all faculties separately, as well as of the UM as a whole. The factsheet is based on alumni research among three cohorts that participated in a survey in 2019. The first cohort graduated in the academic year 2017-2018 (1.5 years prior to the survey), the second in 2013-2014 (five years prior to the survey) and the third in 2008-2009 (ten years prior to the survey). ${ }^{1}$

\section{Position in the labour market}

Of the UM alumni who graduated 1.5 years ago, 93\% report being part of the labour force; of those not currently in the labour force. Almost $60 \%$ of those not being part of the labour force are still studying. ${ }^{2}$ Five years after graduation $86 \%$ is part of the labour force; of those not currently in the labour force $54 \%$ are still studying. Whereas the percentage of respondents being part of the labour force is with 90\% higher ten years after graduation, the percentage of those not being part of the labour force who are still studying is with $11 \%$ larger than among the cohort that graduated five years ago. Whereas this is not surprising, it is interesting to recall that in last year's survey, the percentage of graduates not being part of the labour force and studying was close to zero in the cohort that graduated ten years ago.

Table 1 shows the unemployment rates - that is, the percentage of alumni belonging to the labour force who are currently not working but who are seeking work - by cohort and faculty. As MSI (Maastricht Sustainability Institute, formerly known as ICIS) and MGSoG (Maastricht Graduate School of Governance) have been integrated in SBE (School of Business and Economics) in the academic year 2020-2021, we report the unemploy-

1 The response rates for these graduation cohorts are: $26.6 \%$ for $2017-2018$, 32\% for 2013-2014, 27.9\% for 2008-2009. The response rate for the $2017-2018$ cohort is based on completed surveys.

2 Based on the ILO definition of the labour force. ment rate, as well as the other indicators, both under the old classification of faculties, as well as under the new one. The percentages in between brackets show the S\&E (Science and Engineering) statistics including MSI and MGSoG, as well as SBE statistics without MSI and MGSoG. ${ }^{3}$ Overall, $5 \%$ of the $2017-2018$ cohort is currently unemployed, whereas the earlier cohorts have unemployment rates of $2 \%$. The unemployment rate of the cohort that graduated five years ago is two percentage points lower than the 2012-2013 cohort which participated in the survey last year. ${ }^{4}$ The other cohorts have the same unemployment rate as their comparable cohorts one year ago.

TABLE 01.

Percentage of alumni who are unemployed

\begin{tabular}{|l|c|c|c|}
\hline & \multicolumn{3}{|c|}{$\%$ unemployed } \\
\hline Science and Engineering & 2017-2018 & $2013-2014$ & 2008-2009 \\
\hline Business and Economics & $1(3)$ & $X(3)$ & $X(X)$ \\
\hline Health, Medicine and Life Sciences & 4 & $1(1)$ & $4(2)$ \\
\hline Arts and Social Sciences & 10 & 2 & 2 \\
\hline Psychology and Neuroscience & 12 & 7 & 2 \\
\hline Law & 9 & 3 & 0 \\
\hline Maastricht University & 5 & 2 & 2 \\
\hline X $=$ insufficient data & & &
\end{tabular}

Percentages in between brackets, show SBE statistics without MSI and MGSoG, as well as S\&E statistics including MSI and MGSoG

Unemployment rates vary substantially across faculties, as shown in Table 1. ${ }^{5}$ Unemployment rates above UM average are found among alumni of FPN (Faculty of Psychology and Neuroscience), FASoS (Faculty of Arts and Social Sciences) and LAW 1.5 years after graduation (respectively $12 \%, 10 \%$ and $9 \%$ ). Graduates of FPN also have a relatively high unemployment rate $(7 \%)$ five years after graduation. The unemployment rates of FPN alumni 1.5 and five years after graduation are higher compared to last year's survey. The unemployment rates of FASoS alumni 1.5 and five years after graduation are lower than last year. Alumni of LAW show an increase in

3 This year, we report averages for SBE and S\&E given the old and new situation to be able to compare statistics with those from last year.

4 See ROA-F-2019/4.

5 The unemployment rate is different within FHML. The unemployment rate for Health and Life Sciences alumni is 5\%, $2 \%$ and $1 \%$ respectively. The unemployment rate among Medicine alumni is considerably lower; $0 \%, 0 \%$ and $1 \%$ respectively. 


\section{Factsheet}

ROA-F-2020/3

the unemployment rate 1.5 years after graduation and a decrease five years after graduation. ${ }^{6}$ Overall, alumni of SBE have the lowest unemployment rate among graduates of the cohort 2017-2018. This does not hold for the oldest cohort though. The unemployment rate of FHML (Faculty of Health, Medicine and Life Sciences) graduates is below UM average for all three cohorts.

\section{Trends in unemployment}

Figure 1 shows the trend in the unemployment rate from 2005 to 2019 among UM alumni who graduated 1.5 years before the survey. During the economic crisis, from 2007 till 2013, we observe an increase in unemployment rate. Since 2013, the unemployment rate has fallen. Last year, the unemployment rate was similar to the rate just before the economic crisis. However, we are now observing a slight increase from $4.8 \%$ to $5.5 \%$.

\section{FIGURE 01.}

Trends in unemployment rates 1.5 years after graduation

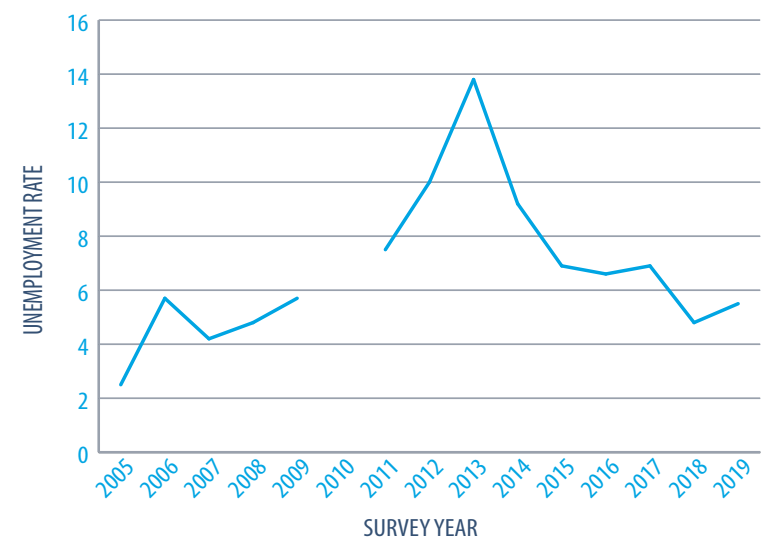

6 Last year, the percentage unemployed among alumni of FPN, FASOS and LAW 1.5 years after graduation was $8 \%, 19 \%$ and $4 \%$.

7 The trends five and ten years ago are not shown as they display little variation over time. See for faculty specific unemployment trends, Table 9 in the appendix.

\section{Vertical and horizontal match}

It is important that graduates have a good match between their education and the requirements of their job, since this determines the extent to which they can use their knowledge and skills. Such jobs are often linked to higher job satisfaction, better career opportunities and less sick leave. ${ }^{8}$

Table 2a shows the vertical match between graduates' current job and their level of education (i.e. whether they are working in a job that requires a master's degree). ${ }^{9}$ The vast majority of UM alumni find a job at master's level. However, we see large differences between faculties and between cohorts. In addition, especially among alumni who graduated 1.5 years ago, we observe a slight decrease in the vertical match compared to last year's survey. On average $69 \%$ of UM alumni find a job at master's level 1.5 years after graduation. This percentage is higher among the cohorts that are graduated longer ago, namely $75 \%$ of the UM alumni who graduated five years ago and $83 \%$ of the UM alumni who graduated ten years ago work at master's level. There are several differences across faculties. Similar to last year, we see relatively high proportions of graduates of all cohorts with a good vertical match among alumni of FHML ${ }^{10}$ and FPN. Almost nine out of ten LAW alumni graduating ten years prior to the survey work at master's level. This is also clearly above UM average. Among LAW graduates, and to a somewhat lesser extent among FHML graduates as well, the probability of working in a job at master's level, is larger the longer ago they have been graduated.
8 See e.g. Lee, Y., \& Sabharwal, M. (2016). Education-job match, salary, and job satisfaction across the public, non-profit, and for-profit sectors: Survey of recent college graduates. Public Management Review, 18(1), 40-64.

9 As last year, we report the percentage of UM alumni working in a job that requires a $\mathrm{HBO}$-master or university-master.

10 There are differences in vertical match among FHML alumni. The percentages of Health and Life Sciences alumni with a vertical match are $63 \%, 76 \%$ and $85 \%$ respectively. In contrast, all Medicine alumni are vertically matched irrespective of cohort. 


\section{Maastricht University Graduate Surveys 2020}

TABLE 02a.

Percentage of alumni with a good vertical match

\begin{tabular}{|l|c|c|c|}
\hline & \multicolumn{3}{|c|}{$\%$ working at master's level or higher } \\
& $2017-2018$ & $2013-2014$ & $2008-2009$ \\
\hline Science and Engineering & $X(69)$ & $X(55)$ & $X(X)$ \\
\hline Business and Economics & $67(67)$ & $69(70)$ & $76(74)$ \\
\hline Health, Medicine and Life Sciences & 72 & 84 & 91 \\
\hline Arts and Social Sciences & 58 & 69 & 68 \\
\hline Psychology and Neuroscience & 76 & 82 & 85 \\
\hline Law & 64 & 78 & 89 \\
\hline Maastricht University & 69 & 75 & 83 \\
\hline
\end{tabular}

$\mathrm{X}=$ insufficient data

Percentages in between brackets, show SBE statistics without MSI and MGSoG, as well as S\&E statistics including MSI and MGSoG

Table $2 b$ shows the percentage of UM graduates that is currently working in their own field of study or a related field of study, the so-called horizontal job match. Most graduates succeed in finding a job in a field that wellmatches their field of study. On average $75 \%$ of alumni find a job in their own or related field of study 1.5 years after graduation; for both alumni who graduated five and ten years ago the horizontal match is $77 \%$. Again, the percentages differ across faculties. Alumni of $\mathrm{FHML}^{11}$ have relatively high proportions of graduates with a good horizontal match. The relatively low percentage of FASoS alumni with a good horizontal match, might be related to the general character of the related master programmes. ${ }^{12}$ Compared to last year's survey, the horizontal match among alumni of most faculties has increased; there is a strong increase among alumni of FASOS 1.5 years after graduation and LAW ten years after graduation. $^{13}$
TABLE 02b.

Percentage of alumni with a good horizontal match

\begin{tabular}{|l|c|c|c|}
\hline & \multicolumn{4}{|c|}{$\%$ working in own or related field of study } \\
\hline Science and Engineering & $2017-2018$ & $2013-2014$ & $2008-2009$ \\
\hline Business and Economics & $X(72)$ & $X(77)$ & $X(X)$ \\
\hline Health, Medicine and Life Sciences & $69(68)$ & $73(73)$ & $79(81)$ \\
\hline Arts and Social Sciences & 85 & 87 & 81 \\
\hline Psychology and Neuroscience & 65 & 62 & 53 \\
\hline Law & 78 & 76 & 73 \\
\hline Maastricht University & 74 & 80 & 84 \\
\hline
\end{tabular}

$X=$ insufficient data

Percentages in between brackets, show SBE statistics without MSI and MGSoG, as well as S\&E statistics including MSI and MGSoG

\section{Income and working hours}

Table 3 shows the median monthly gross income of UM alumni and their average weekly working hours. Maastricht University alumni have a median income of $€ 2709$ per month 1.5 years after graduation. This increases to $€ 3820$ five years after graduation and to $€ 4618$ ten years after graduation. The median monthly incomes are comparable to those of UM graduates from last year's survey. Alumni of SBE, $\mathrm{FHML}^{14}$ and LAW have an income that is comparable to that of other alumni 1.5 years after graduation, but their income increases significantly compared to other alumni five and ten years after graduation. Similar to other years, graduates of SBE have the highest median income. It should be noted that these graduates also report a relatively high median weekly working hours. Except for alumni of SBE, most UM alumni work between 36 and 40 hours per week, equivalent to a full-time job. SBE alumni report to work more hours per week. This also holds for Medicine alumni in some cohorts. ${ }^{15}$

11 There are differences in horizontal match among FHML alumni. The percentages of Health and Life Sciences alumni with a horizontal match are $81 \%, 82 \%$ and $78 \%$, respectively. Among Medicine alumni, these figures are $97 \%, 95 \%$ and $87 \%$.

12 The percentage of FASoS alumni whose current job does not require a specific training direction is $33 \%, 18 \%$ and $26 \%(1.5$, five and ten years after graduation, respectively).

13 For alumni of FASoS who graduated 1.5 years ago we see an increase in horizontal match from $59 \%$ to $65 \%$. For alumni of LAW who graduated ten years ago we see an increase in horizontal match from $74 \%$ to $84 \%$.

14 The median monthly income is different within FHML. Alumn of Health and Life Sciences have a median income of $€ 2590$, $€ 3380, € 3700$ (1.5, five and ten years after graduation, respectively). Whereas alumni of Medicine have a median income of $€ 3600$, $€ 4172$ and $€ 6900$.

15 There are differences in regular working hours per week among FHML alumni. Alumni of Health and Life Sciences have regular working hours of 37, 40 and 35 hours per week, respectively. Whereas alumni of Medicine have regular working hours of 38,47 and 40 hours per week. 


\section{Factsheet}

ROA-F-2020/3

TABLE 03.

Median monthly income and weekly working hours

\begin{tabular}{|l|c|c|c|c|c|c|} 
& \multicolumn{3}{|c|}{ Gross income per month (median) } & \multicolumn{3}{c|}{ Regular working hours per week (median) } \\
\hline Science and Engineering & $2017-2018$ & $2013-2014$ & $2008-2009$ & $2017-2018$ & $2013-2014$ & $2008-2009$ \\
\hline Business and Economics & $X(2585)$ & $X(3800)$ & $X(X)$ & $X(40)$ & $X(40)$ & $X(X)$ \\
\hline Health, Medicine and Life Sciences & $2850(2915)$ & $4700(5000)$ & $6000(6131)$ & $40(40)$ & $44(45)$ & $42(45)$ \\
\hline Arts and Social Sciences & 2850 & 3600 & 4500 & 38 & 40 & 36 \\
\hline Psychology and Neuroscience & 2500 & 3000 & 3630 & 40 & 40 & 40 \\
\hline Law & 2174 & 2992 & 4066 & 38 & 38 & 36 \\
\hline Maastricht University & 2622 & 3825 & 4500 & 40 & 40 & 40 \\
\hline
\end{tabular}

$X=$ insufficient data

Percentages in between brackets, show SBE statistics without MSI and MGSoG, as well as S\&E statistics including MSI and MGSoG

\section{Acquired competencies of UM alumni} In 2019, ROA published a report showing the results of a stated preferences experiment among Dutch employers. ${ }^{16}$ This study was financed by and conducted in cooperation with the UM Student Employability Programme to gain insight into the characteristics and competencies employers expect graduates to have and which skills are decisive when making hiring decisions.

The results indicate that although field-specific knowledge seems to be most important to hiring decisions (related to occupations and sectors for all faculties), having advanced scores on field-specific knowledge is not enough on its own. Employers appreciate a combination of intermediate field-specific knowledge with advanced analytical or social skills more than advanced field-specific knowledge alone. This suggests that it is crucial that students also develop analytical and social skills. More specifically, employers perceive problemsolving capacity to be the most important competency related to analytical skills. ${ }^{17}$ Collaborative skills and communication competencies were perceived to be the most important social skills. ${ }^{18}$

16 See: https://cris.maastrichtuniversity.nl/en/publications/ employability-the-employers-perspective-using-a-stated-preference

17 Other analytical skills (in order from highest to lowest rank) are critical thinking, information processing, research skills and data management.

18 Other social skills (in order from highest to lowest rank) are stress and time management, awareness of a broader context, leadership skills and ethical competencies.
There are two items each in the Dublin descriptors that relate to these analytical and social competencies. In Tables 4 and 5, we report on two competencies related to analytical skills:'solving problems in new or unknown situations' and 'dealing with complex questions/ problems.' We report the extent to which alumni master these competencies and the degree to which their master's programme contributed to the development of these competencies. In Tables 6 and 7, we report similar statistics related to the following competencies related to social skills: 'explaining conclusions or arguments to peers/colleagues' and 'explaining conclusions or arguments to non-experts'.

Table 4 shows the percentage of alumni who indicated that they are able to solve problems in new or unknown situations and deal with complex questions/problems to a (very) large extent. Overall, a relatively high percentage of UM alumni indicated an ability to solve problems in new or unknown situations to a (very) large extent (77\%) and to deal with complex questions/problems to a (very) large extent (80\%).

When asked about solving problems in new and unknown situations, alumni of SBE and LAW scored above the UM average (over $80 \%$ ). ${ }^{19}$ In regard to the statement that relates to dealing with complex questions and problems, LAW alumni again scored above average (91\%). Graduates from FPN scored below

19 Alumni of Health and Life Sciences differed from alumni of Medicine with regard to solving problems in new or unknown situations as a result of their university degree: $74 \%$ and $81 \%$, respectively. 


\section{Maastricht University Graduate Surveys 2020}

average in solving problems in new and unknown situations (70\%), but they scored above average in dealing with complex questions and problems (89\%). ${ }^{20}$

\section{TABLE 04.}

Percentage of alumni who are to a (very) large extent able to solve problems in new/unknown situations and to deal with complex problems

\begin{tabular}{|l|c|c|}
\hline Science and Engineering & $\begin{array}{c}\text { Solving problems } \\
\text { in new or unknown } \\
\text { situations }\end{array}$ & $\begin{array}{c}\text { Dealing with complex } \\
\text { questions/problems }\end{array}$ \\
\hline Business and Economics & $\mathrm{X}$ & $\mathrm{X}$ \\
\hline Health, Medicine and Life Sciences & 81 & 78 \\
\hline Arts and Social Sciences & 75 & 72 \\
\hline Psychology and Neuroscience & 69 & 75 \\
\hline Law & 70 & 89 \\
\hline Maastricht University & 83 & 91 \\
\hline X = insufficient data & 77 & 80 \\
\hline
\end{tabular}

Note: Based on NAE, graduation cohort 2017-2018

Table 5 shows the percentage of alumni who indicated that their master's programme contributed (very) strongly to the development of these skills. In general, $60 \%$ of UM alumni indicated that their master's programme (very) strongly contributed to solving problems in new or unknown situations. At the faculty level, SBE alumni stood out with $68 \%{ }^{21}$ With regard to dealing with complex questions/problems, about 70\% of UM alumni indicated that their master's programme contributed (very) strongly to this competency development. At the faculty level, alumni of FHML ${ }^{22}$ and FASoS scored below the UM average.
20 There were no differences between alumni of Health and Life Sciences and alumni of Medicine regarding dealing with complex questions/problems as a result of their university degree: $72 \%$ and $72 \%$, respectively.

21 There were no major differences between alumni of Health and Life Sciences and alumni of Medicine in how the master's programme contributed to solving problems in new or unknown situations: $60 \%$ and $58 \%$, respectively.

22 There were differences between alumni of Health and Life Sciences and alumni of Medicine in how the master's programme contributed to dealing with complex questions/problems: $62 \%$ and $50 \%$, respectively.
TABLE 05.

Percentage of alumni who indicate that their master's programme has contributed (very) strongly to the development of specific analytical skills

\begin{tabular}{|l|c|c|}
\hline & $\begin{array}{c}\text { Solving problems } \\
\text { in new or unknown } \\
\text { situations }\end{array}$ & $\begin{array}{c}\text { Dealing with complex } \\
\text { questions/problems }\end{array}$ \\
\hline Science and Engineering & X & X \\
\hline Business and Economics & 68 & 69 \\
\hline Health, Medicine and Life Sciences & 59 & 60 \\
\hline Arts and Social Sciences & 57 & 57 \\
\hline Psychology and Neuroscience & 59 & 77 \\
\hline Law & 64 & 72 \\
\hline Maastricht University & 63 & 67 \\
\hline X = insufficient data & & \\
\hline Note: Based on NAE, graduation cohort 2017-2018 &
\end{tabular}

Table 6 shows the percentage of alumni who indicated an ability to explain conclusions or arguments to peers/ colleagues as well as to non-experts to a (very) large extent. Overall, almost $80 \%$ of UM alumni indicated that they are able to explain conclusions or arguments to peers/colleagues to a (very) large extent. We did not observe any major differences between faculties.23 Overall, $70 \%$ of UM alumni indicated that they are able to explain conclusions or arguments to non-experts to a (very) large extent. FASoS alumni scored above the UM average. ${ }^{24}$

23 There were major differences between alumni of Health and Life Sciences and alumni of Medicine in explaining conclusions or arguments to peers/colleagues as a result of their university degree: $69 \%$ and $94 \%$, respectively.

24 There were differences between alumni of Health and Life Sciences and alumni of Medicine regarding explaining conclusions or arguments to non-experts as a result of their university degree: $66 \%$ and $75 \%$, respectively. 


\section{Factsheet}

ROA-F-2020/3

TABLE 06.

Percentage of alumni who are to a (very) large extent able to explaining conclusions or arguments to peers/colleagues and non-experts

\begin{tabular}{|l|c|c|}
\hline $\begin{array}{c}\text { Explaining conclusions } \\
\text { or arguments to } \\
\text { peers/colleagues }\end{array}$ & $\begin{array}{c}\text { Explaining conclusions } \\
\text { or arguments to non- } \\
\text { experts }\end{array}$ \\
\hline Science and Engineering & $X$ & X \\
\hline Business and Economics & 80 & 67 \\
\hline Health, Medicine and Life Sciences & 74 & 68 \\
\hline Arts and Social Sciences & 75 & 74 \\
\hline Psychology and Neuroscience & 76 & 66 \\
\hline Law & 74 & 70 \\
\hline Maastricht University & 77 & 69 \\
\hline
\end{tabular}

$X=$ insufficient data

Note: Based on NAE, graduation cohort 2017-2018

Table 7 shows the percentage of alumni who indicated that their master's programme contributed (very) strongly to the two competencies related to social skills. In general, about two-thirds of the UM alumni indicated that their master's programme (very) strongly contributed to their ability to explain conclusions or arguments to peers/colleagues. At the faculty level, FASoS alumni scored below the UM average. ${ }^{25}$ With regards to explaining conclusions or arguments to non-experts, $55 \%$ of UM alumni indicated that they (very) strongly mastered this skill as a result of their university degree. There are no major differences between faculties. ${ }^{26}$ There is a striking difference between the perceived contribution of master's programmes to the development of the ability to explain conclusions and arguments to colleagues/peers versus non-experts.
TABLE 07.

Percentage of alumni who indicate that their master's programme has contributed (very) strongly to the development of specific social skills

\begin{tabular}{|l|c|c|}
\hline Science and Engineering & $\begin{array}{c}\text { Explaining conclusions } \\
\text { or arguments to } \\
\text { peers/colleagues }\end{array}$ & $\begin{array}{c}\text { Explaining conclusions } \\
\text { or arguments to non- }\end{array}$ \\
\hline Business and Economics & X & X \\
\hline Health, Medicine and Life Sciences & 70 & 56 \\
\hline Arts and Social Sciences & 65 & 57 \\
\hline Psychology and Neuroscience & 57 & 53 \\
\hline Law & 66 & 54 \\
\hline Maastricht University & 70 & 51 \\
\hline X & 67 & 55 \\
\hline
\end{tabular}

$X=$ insufficient data

Note: Based on NAE, graduation cohort 2017-2018

\section{Satisfaction with master's programme at Maastricht University}

Table 8 shows the percentage of alumni who would choose the same master's programme at UM again. Among the youngest and oldest cohorts, $76 \%$ of all UM alumni would choose the same programme at UM again. This percentage is slightly lower for alumni who graduated five years ago, but still over $70 \% .^{27}$ There are differences between faculties but, unlike last year's survey, there are no faculties that stand out. Overall, it can be concluded that the majority of alumni would follow the same programme at UM.
25 There were differences between alumni of Health and Life Sciences and alumni of Medicine in how the master's programme contributed to explaining conclusions or arguments to peers/ colleagues: $62 \%$ and $74 \%$, respectively.

26 There were differences between alumni of Health and Life Sciences and alumni of Medicine in how the master's programme contributed to explaining conclusions or arguments to nonexperts: $55 \%$ and $63 \%$, respectively.
27 The percentages for Health and Life Sciences alumni are 80\%, $70 \%$ and $71 \%$ (at 1.5, five and ten years after graduation, respectively). The corresponding figures for Medicine alumni are $78 \%, 81 \%$ and $85 \%$, respectively. 


\section{Maastricht University Graduate Surveys 2020}

TABLE 08.

Percentage of alumni who would choose the same master's programme at UM again

\begin{tabular}{|l|c|c|c|} 
& \multicolumn{3}{|c|}{ \% of alumni who would choose the same } \\
& $2017-2018$ & $2013-2014$ & $2008-2009$ \\
\hline Science and Engineering & $X(79)$ & $X(72)$ & $X(X)$ \\
\hline Business and Economics & $78(79)$ & $71(72)$ & $80(79)$ \\
\hline Health, Medicine and Life Sciences & 79 & 74 & 77 \\
\hline Arts and Social Sciences & 65 & 66 & 74 \\
\hline Psychology and Neuroscience & 76 & 76 & 67 \\
\hline Law & 72 & 71 & 71 \\
\hline Maastricht University & 76 & 73 & 76 \\
\hline
\end{tabular}

$\mathrm{X}=$ insufficient data

Percentages in between brackets, show SBE statistics without MSI and MGSoG, as well as S\&E statistics including MSI and MGSOG 


\section{Factsheet ROA-F-2020/3}

TABLE 09.

Unemployment

\begin{tabular}{|c|c|c|c|c|c|c|c|c|c|c|}
\hline & $\begin{array}{c}2011 \\
T+1 \\
2009-2010\end{array}$ & $\begin{array}{c}2012 \\
T+1 \\
2010-2011\end{array}$ & $\begin{array}{c}2013 \\
T+1 \\
2011-2012\end{array}$ & $\begin{array}{c}2014 \\
T+1 \\
2012-2013\end{array}$ & & $\begin{array}{c}2015 \\
T+1 \\
2013-2014\end{array}$ & $\begin{array}{c}2016 \\
T+1 \\
2014-2015\end{array}$ & $\begin{array}{c}2017 \\
T+1 \\
2015-2016\end{array}$ & $\begin{array}{c}2018 \\
T+1 \\
2016-2017\end{array}$ & $\begin{array}{c}2019 \\
\mathrm{~T}+1 \\
2017-2018\end{array}$ \\
\hline Science and Engineering & & & & 13.0 & & 4.0 & 4.7 & 4.8 & 6.3 & $x$ \\
\hline Business and Economics & 4.9 & 6.0 & 6.3 & 5.7 & & 3.6 & 0 & 0 & 0.8 & 1.3 \\
\hline Health and Life Sciences & 4.4 & 8.3 & 16.4 & 10.3 & & 9.2 & 8.0 & 7.1 & 2.8 & 5.2 \\
\hline Medicine & 0 & 1.7 & 2.5 & 3.3 & & 2.7 & 0 & 3.9 & 0 & 0 \\
\hline Arts and Social Sciences & 23.9 & 25.5 & 33.3 & 13.7 & & 5.9 & 5.6 & 22.9 & 18.6 & 9.6 \\
\hline Psychology and Neuroscience & 11.4 & 16.7 & 25.6 & 7.6 & & 10.3 & 14.1 & 7.3 & 8.1 & 11.7 \\
\hline Law & 8.8 & 7.1 & 14.3 & 16.2 & & 10.3 & 14.6 & 7.7 & 4.4 & 9.0 \\
\hline \multirow[t]{2}{*}{ Maastricht University } & 7.5 & 10.0 & 13.8 & 9.2 & & 6.9 & 6.6 & 6.9 & 4.8 & 5.5 \\
\hline & $\begin{array}{c}2011 \\
T+5 \\
2004-2005\end{array}$ & $\begin{array}{c}2012 \\
T+5 \\
2005-2006\end{array}$ & $\begin{array}{c}2013 \\
T+5 \\
2006-2007\end{array}$ & $\begin{array}{c}2014 \\
T+5 \\
2007-2008\end{array}$ & $\begin{array}{c}2015 \\
\text { spring } \\
T+5 \\
2008-2009\end{array}$ & $\begin{array}{c}2015 \\
\text { autumn } \\
\text { T+5 } \\
2009-2010\end{array}$ & $\begin{array}{c}2016 \\
T+5 \\
2010-2011\end{array}$ & $\begin{array}{c}2017 \\
T+5 \\
2011-2012\end{array}$ & $\begin{array}{c}2018 \\
T+5 \\
2012-2013\end{array}$ & $\begin{array}{c}2019 \\
\begin{array}{c}\mathrm{T}+5 \\
2013-2014\end{array}\end{array}$ \\
\hline Science and Engineering & & & & & 0 & 6.0 & 0 & 7.4 & 7.5 & $x$ \\
\hline Business and Economics & 5.4 & 1.9 & 0 & 0 & 0.9 & 1.5 & 1.3 & 1.2 & 2.0 & 0.8 \\
\hline Health and Life Sciences & 2.7 & 2.1 & 3.1 & 3.5 & 4.3 & 5.3 & 3.3 & 1.7 & 6.8 & 2.0 \\
\hline Medicine & 1.5 & 0 & 0 & 1.3 & 0 & 4.9 & 0 & 0 & 1.1 & 0 \\
\hline Arts and Social Sciences & 3.8 & 10.1 & 5.7 & 4.8 & 4.4 & 6.7 & 1.5 & 5.7 & 5.0 & 1.6 \\
\hline Psychology and Neuroscience & 10.3 & 4.2 & 0 & 4.3 & 7.5 & 2.5 & 4.9 & 4.4 & 3.1 & 6.6 \\
\hline Law & 5.0 & 0 & 6.8 & 3.8 & 2.6 & 1.8 & 0 & 1.6 & 6.5 & 3.3 \\
\hline \multirow[t]{2}{*}{ Maastricht University } & 4.4 & 2.7 & 3.2 & 2.6 & 2.6 & 3.4 & 1.5 & 2.2 & 3.9 & 2.3 \\
\hline & $\begin{array}{c}2011 \\
T+10 \\
1999-2000\end{array}$ & $\begin{array}{c}2012 \\
T+10 \\
2000-2001\end{array}$ & $\begin{array}{c}2013 \\
T+10 \\
2001-2002\end{array}$ & $\begin{array}{c}2014 \\
T+10 \\
2002-2003\end{array}$ & $\begin{array}{c}2015 \\
\text { spring } \\
T+10 \\
2003-2004\end{array}$ & $\begin{array}{c}2015 \\
\text { autumn } \\
T+10 \\
2004-2005\end{array}$ & $\begin{array}{c}\mathrm{T}+10 \\
2005-2006\end{array}$ & $\begin{array}{c}2017 \\
T+10 \\
2006-2007\end{array}$ & $\begin{array}{c}\mathrm{T}+10 \\
2007-2008\end{array}$ & $\begin{array}{c}2019 \\
T+10 \\
2008-2009\end{array}$ \\
\hline Science and Engineering & & & & $x$ & $x$ & $x$ & $x$ & $x$ & $x$ & $x$ \\
\hline Business and Economics & 2.8 & 0.9 & 0.9 & 0.7 & 1.0 & 0 & 1.6 & 1.1 & 1.1 & 4.2 \\
\hline Health and Life Sciences & 2.0 & 1.2 & 3.1 & 3.7 & 0.6 & 2.6 & 1.6 & 1.4 & 4.5 & 1.3 \\
\hline Medicine & 2.6 & 1.8 & 0 & 2.0 & 3.6 & 1.5 & 1.2 & 0 & 1.7 & 3.4 \\
\hline Arts and Social Sciences & $x$ & $x$ & $x$ & $x$ & 4.3 & 11.5 & 4.4 & 4.6 & 2.0 & 2.3 \\
\hline Psychology and Neuroscience & 0 & 3.8 & 0 & 4.9 & 2.0 & 3.1 & 1.7 & 3.7 & 0 & 0 \\
\hline Law & 0 & 6.1 & 1.6 & 0 & 1.4 & 0 & 0 & 6.9 & 1.7 & 0 \\
\hline Maastricht University & 2.0 & 2.0 & 2.0 & 2.1 & 1.5 & 3.0 & 1.7 & 2.6 & 1.8 & 2.1 \\
\hline
\end{tabular}

$X=$ insufficient data 


\section{Imprint}

(c) Research Centre for Education and the Labour Market (ROA).

Nothing in this publication may be duplicated in any way

without prior written permission from ROA's director.

Research Centre for Education and the Labour Market

Maastricht University

School of Business and Economics

secretary-roa-sbe@maastrichtuniversity.nl

www.roa.nl

\section{Layout}

ROA Secretariat, Maastricht

May 2020 